\title{
Research on the Central Bank of Manchuria's Issue False
}

\author{
Xin Guan \\ Harbin University of Commerce, Institute of Finance, Harbin China, 150028
}

Keywords: Central Bank of Manchuria ; Issue Reserve; Cash Reserve; Fiduciary Reserve

\begin{abstract}
After the September 18th Incident, Japan began to conduct a comprehensive aggression and plunder in the northeast of China. In order to control the financial lifeblood the Japanese Kwantung Army planned and set up a puppet regime, Central Bank of Manchuria. The core issue of finance is currency and the basic problem of currency is monetary value. To maintain the value of Manchukuo banknotes, on June 11, 1932, the puppet government officially announced the implementation of the Pseudo- monetary Law, which had prescribed the issue reserve and related issues for the bank. However, with the outbreak of the war of aggression against China, the amount of paper money issued greatly increased, the issue reserve gradually reduced. After all, it was difficult to maintain the value of Manchukuo currency and the monetary credit went from bad to worse.
\end{abstract}

\section{Introduction}

The 1868 "Meiji Restoration" movement prevented Japan from becoming a semi-colonial crisis, gradually becoming a modern capitalist state with strong military power and economic strength from a backward and closed feudal country. Japan is aware of the reason why the Western powers can be external expansion and the key is the ship's military power. So, Japan began to develop their military power. After having a certain military strength, Japan followed the logic of the Western law of the jungle of the jungle, no longer satisfied with the accomplices of the Western powers, but attempted to obtain the same or even more benefits through the implementation of the "mainland policy".

As early as December 1890, the county government, who had just served as prime minister, put forward the "sovereign line" and "interest line" of invading the mainland in the speech of the congress. "There are two ways of independence, Second, to protect the interests of the line, what is the sovereign line of the territory of the country; what is the line of interest that is related to my sovereign line of security secrets related to the region also, where the state does not guarantee the sovereign line and interest line, the independence of the country, only the guarding of sovereign lines, is by no means sufficient and will also protect the line of interest." This seeks the" decent "theoretical basis for Japanese implementation of the" mainland policy ". Japanese expansion and aggression against our northeast China is also derived from the formation of its "mainland policy". On the evening of September 18, 1931, the Japanese Kwantung Army blew up the wicker lake railway, creating a "nine one eight" incident that shocked the world. After the September 18th Incident, Japan began to carry out comprehensive aggression and plunder of our country's northeast.

Finance is an important area of Japanese economic aggression against China. After the September 18th Incident, Japan directed its aggression to the northeastern financial industry. In the rapid occupation of Shenyang, Changchun, Jilin, Qiqihar and other cities at the same time, to seize the East three provinces official silver, border banking, Jilin Yongheng official silver money, Heilongjiang Province, the official silver and Liaoning Province, Libraries, Bank of China, Bank of Communications and other financial institutions and their affiliated institutions. In order to meet the needs of economic and financial aggression, Japanese Kanto Army together with the South Manchuria Co., Ltd. jointly planned and created the Central Manchuria Central Bank. June 11, 1932, the Manchukuo "monetary law" officially announced. On July 1, 1932, the Manchukuo Central 
Bank was officially opened. Since then, Japan through the Manchukuo Central Bank gradually strengthened the full control of the full Manchu financial industry, firmly in control of the financial lifeline of the Northeast.

\section{The Manchukuo Central Bank Issuing System}

The core issue of money is money, the basic problem of money is the monetary value, and the level of monetary value and the monetary authorities (central banks) to implement the monetary policy is closely related. Modern currency banking believes that the currency issue is the exclusive privilege of the central bank and the currency issue follows the "monopoly issue principle", "credit guarantee principle" and "elasticity issue principle" three principles. Among them, the "credit guarantee principle" means that "the currency issue must have a certain amount of gold or securities to ensure that, that is, through the establishment of a certain issuance of the reserve system to ensure the independent issuance of the central bank in the modern non-cash circulation system, the issuance of paper money to adapt to the objective economic development, otherwise there will be currency instability, affecting the normal development of the economy and society. To do this, the currency issue must be a reliable reserve system for the Basis, insist on the principle of issuing credit guarantee. "In order to maintain the stability of monetary credit, all countries are in the form of legislation on the central bank's currency issue preparation system to make clear. Thus, the core issue of currency issuance is how to set the issue of preparation principles. In theory, as long as the central bank issues currency, the central bank has an equal "extreme debt" on the currency holder, and when the currency holder is required to fulfill, the central bank must have a corresponding of the fund to pay. The central bank to ensure that its currency issue can be redeemed and prepared this part of the fund, that is, "release preparation." The provision for the issuance of money is also different at different times. In the circulation of metal currency, the issue preparation is made entirely of gold. In the circulation of paper money, the issuance preparation according to the content and form of different can be divided into cash preparation and assurance preparation. Cash preparation, also known as the preparation of goods, and more to gold, silver, currency and foreign exchange and other highly liquid assets with a strong liquidity; to ensure that the preparation is more securities and commercial paper can be traded on the market or circulation of securities The form of cash preparation provides a realistic basis for the currency issue, which is conducive to the stability of the currency, but the lack of flexibility is not conducive to the central bank according to the needs of economic development to regulate the issuance of money; to ensure that the form of preparation can solve the cash preparation difficult to achieve flexible distribution Problem, but the central bank to control the difficulty of issuing currency has increased.

June 11, 1932, the Puppet government officially announced the implementation of the Puppet Manifesto "currency law" a total of 13, the "monetary law" on the Manchukuo's currency system has been strictly regulated. The Manchukuo Central Bank vouchers at the time were generally referred to as the "Manchuria Central Bank" for the manufacture and distribution of the Manchukuo Central Bank. Article 2 only provides for the issuance of the puppet full currency, "the net weight of 23.91 grams as a unit of value, called 'round' and its exchange problem did not make any provision. This means that "national currency" is not subject to statutory restrictions on the statutory currency, the exchange policy can be set to Manchu Central

Article 9 and Article 10 stipulate that the provision system for the sale of the puppet-full currency is the "proportional provision system". In the case of cash preparation, Article 9 stipulates that "the issuance of banknotes of the Manchuria Central Bank shall have more than 30\% cash reserves, in addition to silver and gold, but also by gold, silver, reliable foreign currency or gold and silver deposits in foreign banks", The puppet full currency, although the adoption of the silver standard system, but the puppet "monetary law" on the cash preparation in the proportion of gold and silver did not make any restrictions. With regard to the preparation of the guarantee, Article 10 provides that "the guarantee of the puppet full of money is prepared by the government of the Manchukuo government to ensure that the securities and commercial paper do", and there is no absolute limit to the preparation of the guarantee of the puppet. 


\section{The Issued Preparation Situation of the Manchukuo Central Bank}

Japanese fostering the establishment of the Manchukuo Central Bank's first priority is to fully recover the old currency in the Northeast, excluding the original Chinese financial forces and the Bank of Japan and other Japanese financial institutions, through the release of full of money, to establish its own financial dominance, completely complete the so-called "Manchuria" of the "Manchuria" work. July 1, 1932, the Manchuria Central Bank opened the notes issued for the 1.42235 billion RMB, the cash preparation of 0.77849 billion RMB. At this time, gold, silver, dollar, pound, ocean, small ocean and Shanghai silver, silver, silver, town silver and other silver standard currency accounted for $19.1 \%$ of the cash preparation, the Korean bank ticket and gold bank notes cash preparation of 37.5\%. In July 1932, the Central Bank of Manchuria began to force the cash flow in the northeastern part of the country, by reducing the proportion of borrowed from the huge coins and gold and silver, cash preparation of Bank of China funds also increased. In 1934, the Manchukuo Central Bank, while forcibly collecting the old currency in the Northeast, began to accept the North Korean circulation of gold and gold bank notes. However, due to the two banks have a monopoly of the consortium as a backup, the Manchukuo Central Bank did not dare to easily touch until September 1935 by the Japanese and Japanese government issued a "statement" asked the votes and banknotes gradually convergence. At the end of 1936, the proportion of cash and banknotes in cash was 9.3\% higher than at the beginning of the opening. At this stage, the Manchukuo Central Bank strictly abide by the "full moon" monetary law, the cash preparation content is still sound, full of money value to maintain stability.

The Japanese imperialists, in order to change the Northeast into its capital supply base for the war of aggression, began to plunder the strategic material on a large scale by the Industrial Development Five-Year Plan in April 1937. In July 1937, with the full outbreak of the war of aggression against China, in order to support the war needs, "industrial development five-year plan" a substantial expansion of the industry plan to implement the surge in funds required, Japanese financial plunder in Chinese northeast deep Currency issuance also increased significantly. As a result of the "Five-Year Plan for Industrial Development", the gold and silver blocks in the cash preparation have been exported to Anglo-American. According to statistics, Japan will distribute gold and silver from northeast China to London and New York before 1938, among them, the gold is 22.9 tons, silver and silver block for the 1600 ounces. Cash preparation is increasingly short, is not enough goods, the Manchukuo Central Bank will be the Japanese government bonds, the Manchukuo State Treasury bonds, the Japanese gold bank loans, pound bonds, US dollar bonds and so on are included in the stock, to enrich the issue Preparation, which is based on the signing of these secured "Japanese bank loan contract." Since then, "bonds" to replace the "cash" to become a puppet full currency issue preparation, foreign currency bonds as the Manchuria Central Bank currency issue preparation is also seen as "Bank of Japan deposits" on the normal conversion. At the end of 1937, the Manchuria Central Bank's banknotes issued amounted to 3.0749 billion RMB, the surface to see cash preparation as high as $67.7 \%$, but in fact, gold, silver, dollar, sterling, ocean, small ocean and silver standard currency accounted for only $24.1 \%$ Gold tickets, banknotes and Japanese government bonds accounted for 43.6\%. After 1938, the cash preparation of the Manchuria Central Bank notes was almost entirely owned by the Japanese government bonds, the Manchurian government bonds and the gold bank loans. Such as: 1939 is prepared for 52\% of the currency issue, of which 32\% of Manchuria bonds, Japanese bonds, GBP bonds and US Treasury bonds accounted for $17 \%$. The fact that the Manchuria Central Bank is not ready to issue money is clearly.

After the outbreak of the Pacific War in 1941, due to the United Kingdom, the United States have interrupted with Japanese economic and trade exchanges, Japanese financial resources, the Japanese military spending is stretched. In order to alleviate the increasing pressure on military spending, the sale of puppet full money is increasing rapidly. At the end of 1941, the amount of issuance reached 1.137 billion RMB, an increase of 8 times over 1932. To July 1945 issue volume soared to 8 billion RMB, an increase of 19 times over 1932. As of November 1945, after the surrender of Japan, the issuance was as high as $\$ 13.6$ billion, 96 times the amount issued by the Manchuria Central Bank. 
By the end of June 1945, the preparation of the Chubu Chou Central Bank was 33.7\%, or 34\%, compared with $67.7 \%$ at the end of 1937, of which foreign currency bonds, Manchuria bonds and gold deposits accounted for 9\% respectively. Cash preparation ratio is declining and the cash preparation content is increasingly empty, so that the full price of the devaluation of the full of money, full of money and money fell over the money.

July 1932 to July 1945, puppet notes issued to prepare the content is also constantly changing. The proportion of securities issued or guaranteed by the Manchukuo government has been reduced year by year, and the proportion of commodity bills and other private securities has been greatly improved. Before and after 1944, it is guaranteed that almost all of the securities will act as private securities.

Pseudo-Manchuria Central Bank's guarantee reserve changes in the unit: thousand dollars

\begin{tabular}{|c|c|c|c|c|c|}
\hline year & $\begin{array}{l}\text { The certificate } \\
\text { issued or } \\
\text { guaranteed by the } \\
\text { Manchukuo } \\
\text { government }\end{array}$ & $\begin{array}{l}\text { Commer } \\
\text { cial } \\
\text { paper }\end{array}$ & $\begin{array}{l}\text { Other private } \\
\text { securities }\end{array}$ & $\begin{array}{l}\text { Guarantee } \\
\text { the amount }\end{array}$ & $\begin{array}{l}\text { Guarantee } \\
\text { d } \\
\text { preparatio } \\
\text { n rate }\end{array}$ \\
\hline 1932.7.1 & 15100 & 46645 & - & 61745 & $43.4 \%$ \\
\hline 1932 & 47900 & 26116 & - & 74016 & $48.7 \%$ \\
\hline 1933 & 50190 & 11465 & - & 61655 & $47.7 \%$ \\
\hline 1934 & 72069 & 21445 & - & 96514 & $55.6 \%$ \\
\hline 1935 & 86425 & - & - & 86425 & $48.4 \%$ \\
\hline 1936 & 77062 & - & - & 77062 & $30.1 \%$ \\
\hline 1937 & 99393 & - & - & 99393 & $32.3 \%$ \\
\hline 1938 & 209428 & - & - & 209428 & $49.1 \%$ \\
\hline 1939 & 227932 & 71701 & - & 299633 & $48.1 \%$ \\
\hline 1940 & 371143 & 207417 & - & 578560 & $61.1 \%$ \\
\hline 1941 & 661722 & 158304 & - & 820026 & $65.0 \%$ \\
\hline 1942 & 720776 & 234111 & 107721 & 1062608 & $63.3 \%$ \\
\hline 1943 & 624382 & $\begin{array}{ll}1 & 175 \\
397 & \\
\end{array}$ & 170000 & 1969779 & $65.4 \%$ \\
\hline 1944 & - & $\begin{array}{ll}3 & 727 \\
454 & \end{array}$ & 460000 & 4187454 & $70.9 \%$ \\
\hline 1945.6 & - & $\begin{array}{ll}4 & 655 \\
342 & \\
\end{array}$ & 460000 & 5115342 & $66.4 \%$ \\
\hline 1945.7 & - & \begin{tabular}{ll|}
5 & 031 \\
042 & \\
\end{tabular} & 460000 & 5491042 & $68.0 \%$ \\
\hline
\end{tabular}

Source: Northeast Material Regulation Committee Study Group. Northeast Economic Series (Finance) [M]. Shenyang: Northeast Material Regulation Committee Study Group, 1948: 36-37

\section{Conclusion}

The inflation of the Manchukuo country is profound to the people of the northeastern China. The reason for this is inseparable from the release system of the Manchukuo. The Manchu "monetary law" does not stipulate the proportion of cash preparation and guarantee preparation, although it is prepared for "the need for more than 30\% cash preparation". Although the Central Bank of Manchuria has always kept more than $30 \%$ of the cash preparation, but in the actual implementation of the standard put too wide, the proportion of its cash preparation decreased year by year, the issuance of increasingly weak, the preparation of the contents of the ever-changing, the Manchukuo Central Bank will be full of government loans and the Japanese military advances and so on for the results of cash preparation, so that the final cash to fully convert into bonds and borrowing 
certificate, in fact, this time the cash preparation is not as good as the general guarantee to prepare. All this, it reflects the puppet release to prepare for the full release of the full currency on the surface although there is a certain constraint on the surface, but has lost the full amount of money on the full amount of restrictions. The relationship between the preparation of the puppet-full release and the full-fledged currency is entirely controlled by the puppet and the puppet-full currency issue preparation system is entirely for the Japanese financial aggression. The preparation system of the Manchukuo Central Bank is difficult to play a stable currency enhance the role of monetary credit.

\section{References}

[1] Dashanzi, mountain county friends opinion book [M], the original study, 1966: 197.

[2] Zhang Xinzhi, Japanese currency research in China - half a century of financial aggression and looting [M], Beijing: China Financial and Economic Publishing House, 2011: 124.

[3] Xu Chongzheng, money and banking [M], Beijing: China Economic Publishing House, 2001: 204-205.

[4] Zeng Jianzhong, on the central bank in the financial ecosystem in the role of positioning - based on the perspective of monetary circulation analysis[M], China Financial Publishing House, 2011: 111.

[5] Health Liu Rong, Monetary Fundamental Law [M], Hong Kong: Hong Kong Commercial Press, 1993: 39.

[6] Kong Xiangyi, Central Bank General [M], Beijing: China Financial Publishing House, 2009: 104.

[7] Zhang Xinzhi, Japanese currency research in China - half a century of financial aggression and plunder [M], Beijing: China Financial and Economic Publishing House, 2011: 135.

[8] Gao Xiuqing, "nine or eight" after Japanese economic aggression against Chinese northeast [J], Social Science Front, 1993 (5): 198. 